\title{
How Can We Make User Instructions Motivational?
}

\author{
Michaël Steehouder and Nicole Loorbach \\ University of Twente, The Netherlands \\ M.F.Steehouder@Utwente.NL
}

\begin{abstract}
Good technical instructions are often viewed as 'cool, concise and professional', but there are good arguments to pay attention to their persuasive and motivational aspects as well. Until now, only analyses of existing instructions have been published, while guidelines for making instructions motivational are not yet studied carefully. In this paper we present four strategies that can be followed, and an experiment that was meant to test the effects. The results show that motivational elements do increase the user's appreciation of the instructions, but have no effect on performance, self efficacy, or appreciation of the product. However, there are indications that further research may show effects.
\end{abstract}

Keywords: motivational instructions, instructions, documentation strategies, procedures

\section{Introduction}

Technical documents, especially instructions for use, user manuals etc., are usually characterized as being essentially instrumental. They are not designed to be attractive or persuasive, but the predominant quality criterion is usability. This traditional view on technical documents is articulated very clearly by Moore $[1, p .164]$ :

"Rhetoric is persuasive; instrumental discourse shows how to perform actions. [...] Instrumental discourse does not necessarily use reasons or appeals to logic, to the author's character, or to the audience's emotions. [...] An external set of circumstances in a user's environment usually motivates her or him to the instrumental discourse. For example [...] Rhetorical communications and salespeople may persuade customers to buy specific hardware and software, but after the sale, the customers require no persuading to read and apply the installation and operating instructions."

Apart from the objection that Moore uses the term 'rhetoric' in a very narrow, and quite outdated sense today, informative and instructional discourse are not considered as less rhetorical than persuasive discourse [2] - the instrumental and non-persuasive character of technical discourse has been challenged by several authors. William Horton in his book with the meaningful title Secrets of User-Seductive Documents - Wooing and Winning the Reluctant Reader [3] feels that technical writers should take the responsibility of making the reader notice, understand and act on the information. He makes a distinction between 'friendly' and 'seductive' documents. The first enable readers to do and to find; they present information clearly and are readable. Seductive documents, however, get readers to do; they show and teach, they persuade and get read.

Similar views have been advocated in other publications. Gerisch [4], for instance, states that operating instructions, as a part of the total product communication, have their own part in the marketing and sales strategy. They should be 'as fascinating as a thriller' - by text, design and colored pictures. Gabriele Bock [5], after analyzing a number of German and American car manuals, found that older manuals had "a much higher communication quality in terms of richer language, appealing illustrations, and human touch. Modern manuals tend to be abstract, uninhabited, and impersonal'. She illustrates this conclusion by discussing non-verbal elements (pictures) as well as verbal ones (text). Her conclusion is that "the communication model of speaker and listener respectively writer and reader has been replaced by writer and product. Reading means no longer to understand and learn but to receive information impulses and to act appropriately."

The popularity of the "For Dummies" series illustrates that software users do not only want precise and understandable instructions, but also want to enjoy themselves while reading them [6]. Other examples of motivational instructions can be found in popular magazines such as the Dutch PC Idee which offers articles about 'Computing your biorhythm with MS Excel' or 'Laying out you garden with MS PowerPoint'. This tendency of pleasant instructions seems in line with trends in software design and human factor literature to consider the importance of 'designing for pleasure' [7], [8]. The needs of customers go beyond usability and usefulness: they want products that give them pleasure and joyful experiences. 
Summarizing, we find the following motives for making instructions (more) persuasive or enjoyable:

- to motivate users to read and to follow the instructions more carefully (compliance);

- to increase the appreciation of the product (marketing)

- to make the instructions more communicative (author and reader)

- to meet the user's wish to enjoy himself with the product and the instructions.

\section{Means to make instructions more motivational}

Although the idea of making instructions more motivational gets increasing support - at least in practice - there are only occasional publications that examine strategies that can be followed to achieve that goal. The following is a summary of the strategies that are suggested by some authors (in particular [3] and [6]).

\subsection{Create appropriate personas}

One of the important rhetorical aspects of any document is the rhetorical author-reader relationship expressed in the document and perceived by the reader. Halse [9], for instance, found that computer manuals for novices express certain author roles (friend, helper, expert, non-technical person like the reader) and certain reader characteristics (young, professional, naive, afraid to do things wrong). By considering these aspects, Halse states, manual writers will surely produce better manuals. Coney [10] points out that technical writers do not only think of their readers as 'real persons', but also create several roles for the reader, such as 'receiver of information'- a very neutral role - 'user', decoder', 'professional colleague' and in a rhetorical sense 'creator of meaning'.

Steehouder [11] shows that technical writers create both author and reader personas to make their instructions more attractive. From an analysis of 60 Dutch user instructions for electronic consumer products, he identified four different author identities: the manufacturer of the product, an unidentifiable third person, an identifiable third person, and an apparently fictitious person (e.g. a comic character). These author personas play different roles, such as the technical instructor, the teacher, the tutor, the salesman, or the advisor. On the reader's side, different roles can be identified as well, such as the customer, the mechanic, the (potential) complainer, and in particular: the technical operator and the user.

Since the publications cited here are merely analytical, they don't provide criteria for an appropriate persona as such. However, it seems plausible that an 'invisible' author, as we find in most instructions, is at least less motivational than some friendly guide, coach, teacher or tutor, showing enthusiasm for the technical product, a willingness to help and interest in the reader's needs and feelings. The "For Dummies" books provide excellent examples of such personas, even showing irony to be even more attractive [12].

\subsection{Using narratives}

Most people like to read stories rather than instructions. When we look into the popular magazines such as $P C$ Idee, it strikes that most articles start with presenting persons who tell us about their personal needs ('I wanted. to compute my biorhythm') and show their enthusiasm about the use of the computer software for meeting these needs. Narratives can take the form of testimonials, anecdotes, stories, examples, etc.

\subsection{Make goals attractive}

Presenting the goals of a procedure is a common use in instructions [2]. But to make instructions more motivational, it is possible to extend the usual how-to question or gerund form to a passage that has the character of a promise. Goodwin [12] describes two strategies to motivate users directly: the ekphrasis and the late point-of-attack time sequencing. The ekphrasis means that a time-out is taken in the middle of the narrative (the instructions) to look at what has been achieved so far and what still lies ahead (e.g.: "If you have gone through chapters 4 and 5 , then you are able to use all the call functions of the Malibu 300. Now, it is time to explain how you will be able to enjoy some of the luxury providers of the Malibu 300").

The late point-of-attack time sequencing means that the results of a certain action are described (effect and advantages) before the accompanying instructions are given (e.g. "Would you like to have your hands free to take notes or look something up? In that case, you can call hands free.... You can also let other people listen to your conversation via the base station. On page 22 , Irma will explain why this may come in handy").

\subsection{Encouraging confidence}

Confidence or self efficacy is one of the most important factors that influence the success of learning processes in general, and undoubtedly this also holds for the success of user instructions. Confidence can be promoted with elements that are mentioned before, such as examples, narratives and testimonials ('If this person was able to do it, I will be able to do it'). But it is also possible to ensure the user explicitly that a task is doable: 'This function may'seem difficult, but I assure you: if you try it out, it will prove to be quite simple'. 


\section{Put it to the test}

To investigate whether these motivational strategies have a provable effect on the reader, we conducted an explorative experimental study, using two versions of a manual of a quite complex telephone system, the Malibu 300 . One version did not contain motivational elements, and it was called the technical instruction manual (T); the other contained a number of added motivational elements such as those described above, and was called the motivational instruction manual (M).

Forty students of the University of Twente participated in the study; 20 of them were engineering students, 20 were students of social sciences. Both groups consisted of 10 males and 10 females.

We investigated four possible effects of the motivational elements that had been added to the $T$ version:

- Text appreciation. The participants gave their judgments by completing semantic differentials that reflected affective aspects (fascinating/boring, friendly, personal, professionally/popularly written, good) as well as cognitive aspects of the text (logically set up, easy to use, clear, orderly, succinct/longwinded, written towards users/functions, simple, useful). A grade for the entire instruction manual was asked as well.

- Performance. The participants had to perform 12 tasks with the telephone. To measure the accuracy we observed whether the tasks were completed correctly. To measure the efficiency, we calculated the efficiency coefficient [13]: the minimum number of keystrokes needed to complete the task, divided by the actual number of keystrokes that the participant actually used. This results in a number between 0 and 1; the latter meaning that the ideal procedure has been followed to complete the task.

- Self efficacy. Participants were asked to indicate how well they believed they would be able to successfully perform twelve tasks with the Malibu 300. Eight of these tasks belonged to the set that had to be performed during the experiment, four did not. The self efficacy questions were asked twice: before and after the participants carried out the tasks. In the afterquestionnaire, the questions about the eight practiced tasks were modified; the participants were asked whether they thought they were able to perform the tasks successfully in the future without using the instructions.

- Product appreciation. The participants completed semantic differentials that reflected a variety of qualities (good product, easy to use, looking standard/unusual, modern/old-fashioned, beautiful, product with a lot of possibilities, looking like design/function, good bargain). Questions were also asked to determine the willingness to buy the Malibu 300 (purchase intention).

\subsection{Procedure}

Each participant was tested individually in a session that lasted one hour on average. After an introduction by the experimenter, the participant was asked to skim the assigned instruction manual for three minutes. Next, he or she was asked to skim chapter 6 (which contained the relevant information for the assignments in the experiment), again for three minutes.

After skimming, the participant filled out the first questionnaire, which contained questions about text appreciation, self-efficacy, product appreciation and purchase intention.

Next, the participant performed the assignments while thinking aloud. After de last assignment, the participant filled out the second questionnaire, which contained the same questions as the first one (some modified; see above).

After the participant had filled out the second questionnaire, the alternative version of the instruction manual was shown with the request of skimming this version for four minutes. Next, the experimenter asked the participant which of both versions he or she preferred, and why ("Suppose, you just bought the Malibu 300 or got it as a present and you are allowed to choose which of these two instruction manuals you would receive with it. Which instruction manual would you choose?").

\section{Results}

\subsection{Text appreciation}

Table 1 shows that the $\mathrm{M}$-version of the instructions was higher appreciated in some respects. Remarkably, the results are different for the first measurement (after skimming the text) and for the second measurement (after practicing with the telephone). Table $1 \mathrm{~b}$ shows that four judgments differed significantly before and after.

It also strikes that the differences did not only occur with the affective aspects of the texts (attractiveness, written towards users), but also with the cognitive aspects (simplicity and succinctness). 
Table 1. Mean text appreciation before and after the assignments.

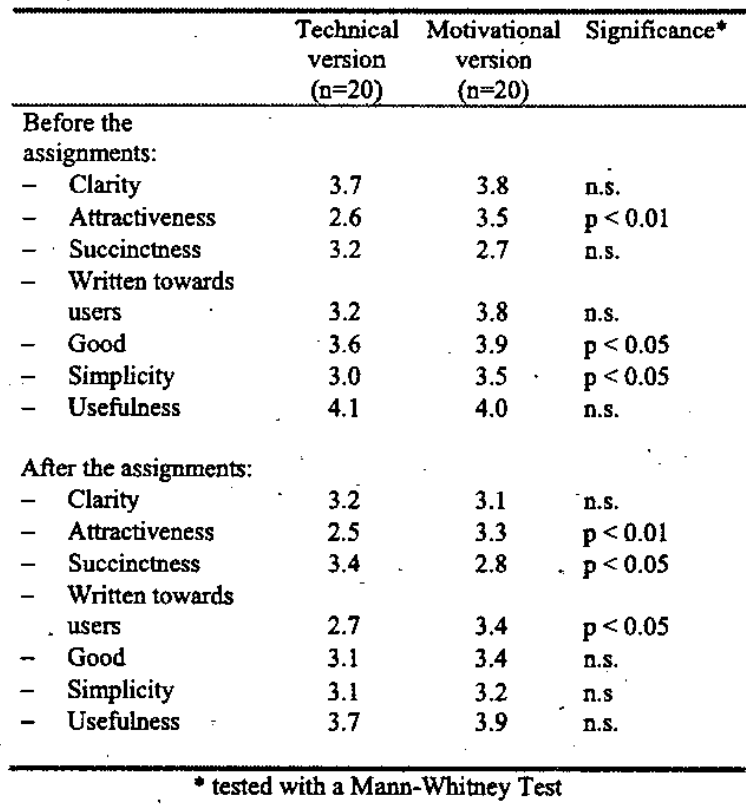

Table 2. Differences in text appreciation before and after the assignments.

\begin{tabular}{lccl}
\hline & $\begin{array}{c}\text { Before the } \\
\text { assignments } \\
(\mathrm{n}=40)\end{array}$ & $\begin{array}{c}\text { After the } \\
\text { assignments } \\
(\mathrm{n}=40)\end{array}$ & Significance* \\
\hline Clarity & 3.7 & 3.2 & $\mathrm{p}<0.01$ \\
Attractiveness & 3.0 & 2.9 & n.s. \\
Succinctness & 2.9 & 3.1 & n.s. \\
Written towards & & & \\
users & 3.5 & 3.0 & $\mathrm{p}<0.05$ \\
Good & 3.7 & 3.2 & $\mathrm{p}<0.01$ \\
Simplicity & 3.2 & 3.2 & n.s. \\
Usefulness & 4.0 & 3.8 & $\mathrm{p}<0.05$ \\
& & & \\
\hline & & & \\
\end{tabular}

\subsection{Performance}

The results did not show a significant difference in task performance, nor in accuracy, nor in efficiency. There was only one exception. One of the tasks showed a difference between the T-version ( 4 good answers) and the M-version (15 good answers). A closer look to these results suggested that these results were probably due to the fact that the M-version contained (almost) the verbatim answer on the question in one of the added exămples.

\subsection{Self- efficacy}

The answers on the questionnaire concerning self efficacy did not show significant differences between the $\mathrm{T}$ - and the $\mathrm{M}$-version of the user instructions, not before nor after the assignments. However, as table 3 shows, there were significant differences between the answers given before and after, especially for the non-performed tasks.

Table 3. Differences in self-efficacy before and after the assignments.

\begin{tabular}{lccc}
\hline & $\begin{array}{c}\text { Before the } \\
\text { assignments } \\
(\mathrm{n}=40)\end{array}$ & $\begin{array}{c}\text { After the } \\
\text { assignments } \\
(\mathrm{n}=40)\end{array}$ & Significance* \\
\hline $\begin{array}{l}\text { Performed } \\
\text { tasks }\end{array}$ & 4.38 & 4.53 & $\mathrm{p}<0.05$ \\
$\begin{array}{l}\text { Non-performed } \\
\text { tasks }\end{array}$ & 3.98 & 2.88 & $\mathrm{p}<0.01$ \\
\hline & * tested with a Wilcoxon Signed Ranks Test
\end{tabular}

\subsection{Product appreciation}

There were no significant differences between the $T$ version and the $M$-version regarding the appreciation of the Malibu 300. However, we found significant differences in the judgments before and after the assignments again, as shown in table 4.

Table 4. Differences in product appreciation before and after the assign ments.

\begin{tabular}{lccl}
\hline & $\begin{array}{c}\text { Before the } \\
\text { assignments } \\
(\mathrm{n}=40)\end{array}$ & $\begin{array}{c}\text { After the } \\
\text { assignments } \\
(\mathrm{n}=40)\end{array}$ & Significance* \\
\hline Attractiveness & 2.9 & 2.8 & n.s. \\
Usability & 3.6 & 3.3 & $\mathrm{p}<0.05$ \\
Good & 4.0 & 3.8 & $\mathrm{p}<0.01$ \\
Possibilities & 4.2 & 4.1 & n.s. \\
& & & \\
\hline & & & \\
& & & \\
& & tested with a Wilcoxon Signed Rank Test
\end{tabular}

At the end of the experiment, no difference was found in preference for one of the versions: 14 out of 20 participants preferred the manual they hadn't used during the experiment.

\section{Conclusions}

The results of this experiment do not support the idea that motivational elements increase the performance, self efficacy and appreciation of the product. We only found significant differences in the appreciation of the instructions themselves, which were constantly in favor of the motivational version. The obvious conclusion is that motivational elements do increase the pleasure of reading, without harming performance or self efficacy. 
An explorative secondary analysis of the results showed that there were significant correlations to certain aspects of text appreciation and other measures. For instance, we found (significant) correlations between 0.36 and .63 between text appreciation and product appreciation. These results indicate that it might be useful to continue our research, probably with other instructions, and perhaps more refined questionnaires and other types of participants.

The significant differences between the answers given before and after the assignments catch the eye. Apparently, the experience of doing things with the text changed the participant's appreciation about the instructions, where different aspects were judged differently. Moreover, the experience caused a dramatic decrease in the self efficacy, in particular related to tasks that were not part of the test. It seems that the participants overestimated their capacities after a short look into the manual, while the actual use of it confronted them with reality.

\section{References}

[1] Moore, P. "Rhetorical vs. instrumental approaches to teaching technical communication," Technical communication, vol. 41, pp. 163-173, 1997.

[2] Farkas, D. K. "The logical and rhetorical construction of procedural discourse," Technical communication, vol. 46, pp. 42-54, 1999.

[3] Horton, W. Secrets of user-seductive documents. Wooing and winning the reluctant reader. Arlington VA: Society for Technical Communication, 1997.

[4] Gerisch, L. "Towards self-advertising operating instructions," presented at Disappearing borders. Forum 95 international conference for technical communicators, Dortmund, 1995.

[5] Bock, G. "The disappearance of communication culture in technical documents," presented at Disappearing borders. Forum 95 international conference for technical communicators, Dortmund, 1995.

[6] MacDonald, M. P. "Can a Manual entertain?," Intercom, pp. 14-17, June 2001.

[7] Cooper, The inmates are running the asylum. Indianapolis: Sams, 1999.
[8] Jordan, P. W. "Pleasure with Products: Human Factors for Body, Mind and Soul," in Human Factors in product design: current practice and future trends. London: Taylor \& Francis, 1999, pp. 206-217.

[9] Halse, R. "Computer manuals for novices: the rhetorical situation," Journal of technical writing and communication, vol. 16, pp. 105-120, 1986.

[10] Coney, M. B. "Technical readers and their rhetorical roles," IEEE Transactions on professional communication, vol. 35, pp. 58-63, 1992.

[11] Steehouder, M.F. "Achter de knoppen. Over technische communicatie en communicerende technici," ("Behind the buttons. About technical communication and technicians communicating"): Dinkel Instituut, Enschede, 2000.

[12] Riley, K. "About Face: Comparing Positive Politeness in Dummies and Conventional Software Documentation," presented at IPCC 2003: The Shape of Knowledge, Orlando, 2003.

[13] Glasbeek, H. "Ik doe wel wat hier staat, maar hij niet." Een onderzoek naar vaardigheidverwerving door gebruikers van leshandleidingen bij een computerprogramma ("I do what it says, but it does not" A study into skill acquisition by users of software tutorials"): Dissertation Utrecht University, 2001.

\section{About the Authors}

Michaël Steehouder holds the chair of Technical Communication at the University of Twente. His research interests include the design of instructions, rhetorical aspects of Technical Communications, and interactive forms of user support such as user forums and helpdesks. $\mathrm{He}$ is associate editor of IEEE Transactions on Professional Communication and member of the IEEE PCS Adcom. He is also chair of STIC, the Dutch society for Technical Communication.

Nicole Loorbach is a junior researcher at the University of Twente. Her research interest includes text design, in particular the motivational elements in technical documents. 


\section{Appendix}

\section{Examples from the manuals}

The Technical version in Figure 1 contains streamlined step procedures. The Motivational version in Figure 2 contains additional elements.

Page 43 of the technical version (Figure 1) corresponds with pages 50 and 51 of the motivational version (Figure 2). On these pages, three passages are added. Translated:

\section{Assigning a melody to VIP groups}

Assigning a special melody to phone numbers from VIP groups is possible when you have multiple handsets but also when you only have one handset. The latter is Simon's case. He'll tell you himself why he has assigned special melodies to VIP-groups:

Picture this: you're relaxing at home on your day off and then the phone rings. Should I answer? What if it's someone from the office... they might need me after all... But it may also be David or Eric. Maybe they want to get together! Fortunately, the people at KPN took this into account. In my display, I can see who's calling. My Malibu 300 has an extra advantage: in the general phone book, I can divide people into two VIP groups, namely: people who are allowed to interrupt you at a time like this (friends and family) and people who aren't (colleagues). Because I gave every VIP group it's own melody, I don't even have to get up to decide whether or not to pick up the phone! That's what I call relaxing on your day off? [caption reads: Simon Achterberg, 32 years]

We've already met the Schipper family on page 46 . They own one station and three handsets of the Malibu 300 . Since their phone rings all the time, they use the melodies for VIP's differently. Because most of the calls are for the teenage daughters Anne and Roos, they made the following division: in the general phone book, family, friends and colleagues of Joke are VIP group 1 and family, friends and colleagues of Kees are VIP group 2. Because a different melody was assigned to each VIP group, everyone of this family knows when an incoming call is for Joke and when a call is for Kees. When they hear the standard melody, nine out of ten times, it's for Anne or Roos.

You can assign a melody to VIP groups in the following manner:

[same streamlined step procedure as in the technical version] 
Opgeslapen tetefoonnummer bellen -

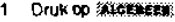

- In het disolay verschijr de erste naam ut het agemene

nummergeheugen.

2 U het 2 mogetjkteden:

- Elader met - naat de gewenste naam

- Toets de egrste letter yan de gewenste namin met de cif rentoetsen (zie paragraa 6.1). Blader vervolgens ma * naar de gewenste naam

3 Druk ao - of op riaked

- In het display verschint 1 . Het telefoonnurmer word gebeld Na enkete secondenverschint de gesprekstijd in het display.

\section{(1) Dijuen}

1 Drek on soromer.

- In het display verschjint de eerste namuthet algemene numnergetieugen

2 Unebl 2 mogeljikhoden:

- Blader met - naar de gewenste nzam.

- Tods da eerste better van de gewenste naamin met de cilyentoetsen (zie paragraa 6.1). Bladar vervolgens mot * nar de gewenste naam

3 Druk op ondie.

4 Drkop witrios.

5 Onk eventueel op awastow om de naarn te wizigen.

6 Druk op ons

I Druk eventseel on

D Druk op ows.

8 Druk op ow.

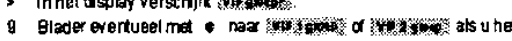
telefoonnummer will opsiaen in één yan de twee VIP-groepen

10 Dnuk $\infty$ o o.

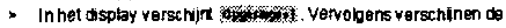
ovge slagen naam en het oxgestagen nummer in het display. Als net teletoonnummer is opgesigen in de eerste VIP-groep. verschijnt bi hot nummer verschstagen in de tweede VIP-groep, ver schint bi het nurrmer 11 U hebl 3 mogelijkeden:

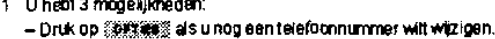

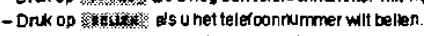
- Orik op eso orn terug te keren nas de ruststand.
Opgestaden neam en nummer wasen

1 Druk op sus anter.

- In het display verschijt de erste naam ut net algemene

nummergeheugen.

2 Unebt 2 mogelijkheden:

- Blader ma - naar de gewenste naam

- Toels do eerste letter van de gewenste nam in mat de

ciferloetsen (zie paragraa $\{6,1$ ).

Blader revoloensmol naar de gewente nam

3 Druk on on

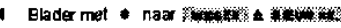

5 Oruk op surition.

In het display verschint twatit. Vervolgens verschilnt de volgende naamen het volgende nummer uit het algemene

nummergeneugen.

6 Uhesis 2 mogelikteden:

-Druk op of otrites als u nog een telefaconnummer wit wissen. -Druk op te om terug te kerennzar de ruststand.

Metod bel signad insteken voor MP.

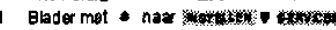

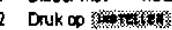

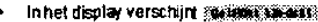

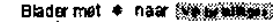

Druk oo ox.

- In het displa verschijn Im warkwa.

5 Unebit 2 mojelijkhedien:

-Druk op ox: ats u de malode voor de eerste VIP. groep wh instellen. Gaverder met stap?

instelen. Gaverder met slap?.

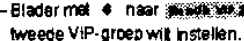

twreede ViP.

- In het displaf verschijt de ingestet de melodie.

Uhoort de ingestelde melodie met het incestelde volume.

Elader met - naar de gewenste melode. U kunj kiezen uit 5 melodioen

(1)

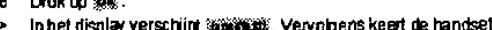

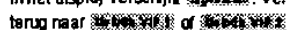

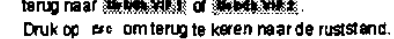

Figure 1. Technical version of the manual. 
Opgestagen naarnen nummes wissen

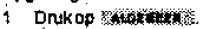

In hed dspotay verschint de eerste naàmult hat algemen telefoontook.

2 U hebt 2 mogelikheden:

- Heder met - naar de gawenste raam

- Tcets de eerste letter van de gewenste naam in met de ciffentostsen (zie paragraat 6.1).

Blader vervolgens inet i naar de ggwenste naam

3 Dnkop on

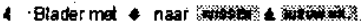

5 Oruk on mask.

- In het display verschipt wew Vevolgens verschint de volgende nam en het voigende nummer ul bet akgemene tetefoonboek

6 U neb! 2 mogelikheden:

- Druk op ofotites alsu nog een telofoonummer wit wissen. - Druk op om terug te keren naar de ruststand.

Watodie betsipnad instelan voor VP-gropen

Het insteilen van een spexiale melode voor telefounnummers ult ViP. groepen is mogelijk wannees u meerdere handsets, mar ook wameer u slechts éńn handset hebt. Ot laat ste is het geval bi Simon. Hi vertel

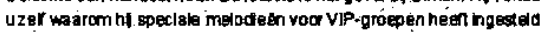

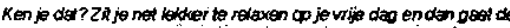
relocon Noet thopnemen? Stel da het iemend vas kantoor is.

hebcen $z e$ me misschian toch nadig vanctag Naar bet kan oc

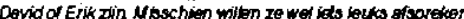

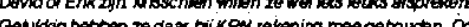

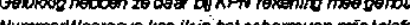

Nummerweergave kan ik in fot schermvan mintekefocon zien wie $\alpha$

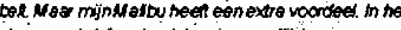
ogemene tolucon book kin a namelik woe groepen mensen irdele in in zcoeneamos Vifigroepon Dus - mensen die je ap zo'n mament wel inosen storen

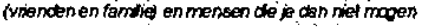

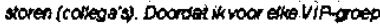
rem ch

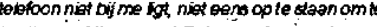
bostiosen of ik oneem Dat noem k nou retaxen as

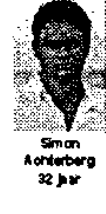
jevire cog
De famile Schipper heboen we al leren kennen op blateide 46 . Zij hebben èén basisstatión en drie hand́sets van da Malibu 300 . Zij maken op sen andere manter gebrikvan deverschillende melodieén voor VIP-groepen. In hun huis gaz' nametik regeimatig de teletoon. Omdat verreweg de meeste tefefcortles voor de dochters Anne en Roos zin, hebben ze do volgende indeling gemaakt in het al gemene tolefoontsoek staan famile, vienden en collega's van Jokg in VIP. groep 1 enfarilie, vrlenden en coilieg's'syan Kees stasn in VIP-groep

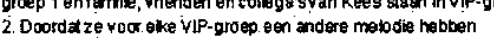
2. Doordát ze wock eke VIP-groep. enn andere melodie habben voorstld, weet ledereen in hivis wanneer ervoor Kees en wanneer teen keer telefóon voor Anne of Roos.

U kunt de melodle van beksignalen yan de VIP-groepen op de volgende marler ingellen:

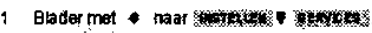

D Drsk op thin

In het displaj verschin

3 Blacer met * nar bux whom

4 Druk op 然.

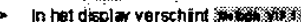

5 Uhet 2 mogelitheden

Uhets 2 mogeltheden

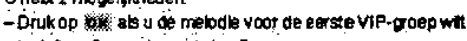

instalen Qaverder met thap 7 .

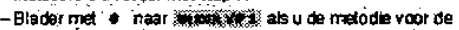
twoede VIP-groep wilt instetlen.

6 Druk op os.

- In het display verschini de Ingestelde melode.

unoor de ingestelde molodie met het ingestelde volume.

7 Blader met - naar de gewenste metodie. U kunt lideren ull 5 melodeen.

- Druk op

- In het displaj verschilmt why vervolgens keent de hindset

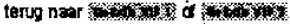

9 Druk op soo om terug te keren raar de rustatand.

6.3 Hand sotiteidefontoent

In het hardset telefoconbicek van de Mafibu 300 kurt 450 telef con nummers met namen opsiagn. De tetfoomurmers mogen ut

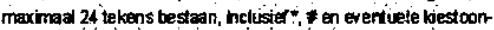

Figure 2. Motivational version of the manual. 